\title{
Optimal Planning and Design for Sightseeing Offshore Island Microgrids
}

\author{
Yunzhi $\mathrm{Fei}^{1}$, Yongxiu $\mathrm{He}^{1}$, Fenkai $\mathrm{Chen}^{1, *}$, Peipei You $^{2}$, and Hanbing Zhai ${ }^{1}$ \\ ${ }^{1}$ School of Economics and Management, North China Electric Power University, Beijing, 102206, China \\ ${ }^{2}$ State Grid Energy Research Institute CO., LTD, Beijing 100052, China
}

\begin{abstract}
A method of optimizing the design of the sightseeing island micro-gird is described and combined with the actual case, simulation analysis is performed using the HOMOER. The simulation results show that for the sightseeing offshore island with limited natural resources, diesel-renewable-storage mixed micro-grid is more suitable for practical application and is the best choice. In the planning of sightseeing island microgrid, environmental protection requirements and system full standby needs should be taken into account.
\end{abstract}

\section{Introduction}

In the traditional offshore island power supply, the diesel and battery energy storage system dominates, but there are many problems in this method ${ }^{[1]}$. First, the offshore island ecological environment is relatively fragile, and the use of diesel power generation will lead to ecological damage. Second, in the offshore islands, it is difficult to obtain fuel for power generation, which can result in high generation costs.

Renewable power generation technology is a feasible way to solve the problem of island energy supply ${ }^{[1]}$, but the traditional renewable-only system is affected by weather factors, and it is difficult to provide stable power ${ }^{[2]}$. With the development of energy storage technology and microgrid control technology ${ }^{[3-4]}$, the integrated system consisting of renewable power and energy storage has become the optimal solution for island energy supply ${ }^{[5]}$.

Current research on microgrids includes two categories: one is to consider physical optimization problems specifically. Based on the decimal optimal retention genetic algorithm, the independent microgrid model with desalination is optimized for the comprehensive life cycle net cost, renewable energy utilization rate and pollutant emission level ${ }^{[6]} ;$ a systematic analysis is made of the energy management of the island microgrid and the optimal configuration of the microgrid ${ }^{[7-9]}$. The above literatures study the microgrid networking from two aspects of control theory and planning theory.

The rest of the paper is organized as fellows: Section 2 presents the networking method, Section 3 illustrates the establishment of the homer model, Section 4 compares characteristics of different networking schemes, and the results are presented and discussed, and finally Section-5 presents the summary and conclusions of this work..

\section{Sightseeing offshore island microgrid networking analysis method and process}

\subsection{Problem definition}

When planning a grid for a sightseeing offshore island, environmental factors and economic factors need to be taken into consideration. Environmental factor refers to waste emissions from power generation processes, including carbon dioxide, carbon monoxide, sulfur dioxide, etc. Economic factors usually consider the net present cost (NPC) and the levelized cost of energy (COE), to calculate the net present cost the following equation was used:

$$
C_{\mathrm{NPC}}=\frac{C_{\mathrm{TAC}}}{\mathrm{CRF}_{(i, N)}}
$$

Where, $C_{\mathrm{NPC}}$ is the net present cost, $C_{\mathrm{TAC}}$ is the total annual cost, $i$ is the annual real interest rate (the discount rate), $N$ is the number of years, $\mathrm{CRF}_{(i, N)}$ is the capital recovery factor, and it is calculated as the following equation:

$$
\mathrm{CRF}_{(i, N)}=\frac{i \times(1+i)^{N}}{(1+i)^{N-1}}
$$

Also, to calculate the levelized cost of energy, the following equation was used:

$$
\mathrm{COE}=\frac{C_{\mathrm{TAC}}}{Q}
$$

\footnotetext{
*Corresponding author: 1090962561@qq.com
} 
Where, COE is the levelized cost of energy, $Q$ is the total electricity consumption of the island load.

\subsection{Networking process}

Taking into account the development needs of sightseeing islands and the traditional island microgrid configuration $^{[7]}$, the following island microgrid networking process is summarized.

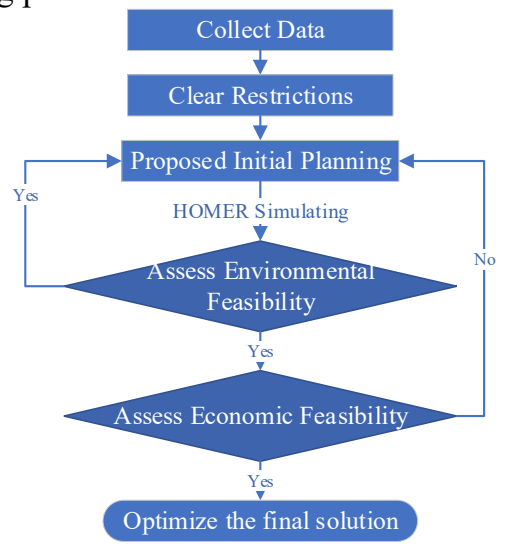

Fig. 1. Island microgrid networking process.

\subsection{The hybrid optimization platform: HOMER}

HOMER simulates the scale and configuration of different renewable energy systems based on the net present cost (NPC), the total installed and operating cost of the renewable energy hybrid power generation system in its life cycle ${ }^{[7-9]}$.

\section{HOMER model}

This evaluation process mainly uses the HMOER model ${ }^{[8]}$. When planning for microgrid, the required data generally includes the following five categories ${ }^{[7]}$ : (1) self-resource Data; (2) island power grid data; (3) load demand data; 4) equipment data; (5) limited data and policy.

The following is a description of the actual case:

\subsection{Natural resource data}

The paper selects a natural eco-tourism island in the development of southern China as the research object. The geographical coordinates of the island are located at $114^{\circ} 37^{\prime} 58$ " east longitude and $22^{\circ} 27^{\prime} 47 "$ north latitude. According to the query, the average annual wind speed of the island is $6.4 \mathrm{~m} / \mathrm{s}$. The average annual sunshine hours are $1766.5 \mathrm{~h}$, and the average annual total solar radiation is $5137.7 \mathrm{MJ} /(\mathrm{m} 2)$.

The monthly wind speed and light radiation intensity changes are shown in Fig. 2. and Fig. 3.:

\subsection{Island power data}

The island currently has an installed capacity of $300 \mathrm{~kW}$, of which the two villages on the island have $100 \mathrm{~kW}(20$
$\mathrm{kW}+30 \mathrm{~kW}+50 \mathrm{~kW})$ and $200 \mathrm{~kW}(50 \mathrm{~kW}+150 \mathrm{~kW})$ respectively.

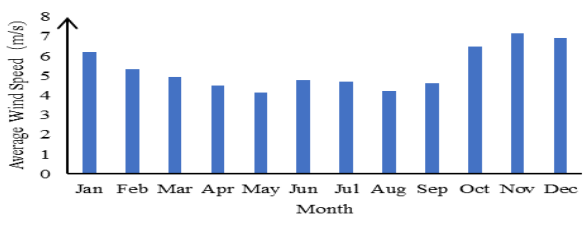

Fig. 2. Wind speed.

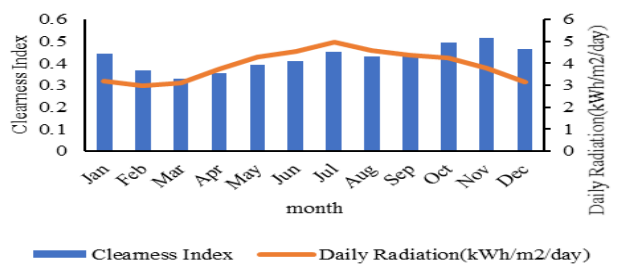

Fig. 3. Clearness index and daily radiation.

\subsection{Load demand data}

The island is positioned as a sightseeing eco-tourism island, so the load on the island can be roughly divided into two categories: residential electricity and hotel commercial electricity. Since the island has not yet achieved full power supply and is undergoing development, load forecasting is used to obtain the load demand of the island.

For residential users, referring to the load of residents of other electrified islands in the province where the island is located, it can be concluded that the load change of the resident users of the island is shown in Fig. 4.

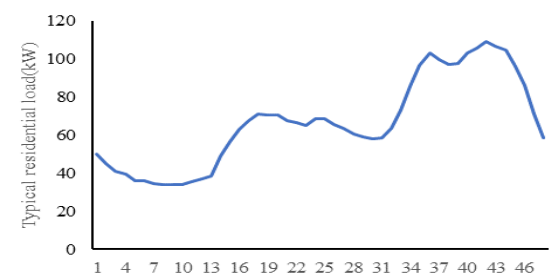

Fig. 4. Typical residential daily load curve.

Analysis of the province's hotel load data can be obtained from the typical hotel load changes in the province, as shown in Fig. 5.

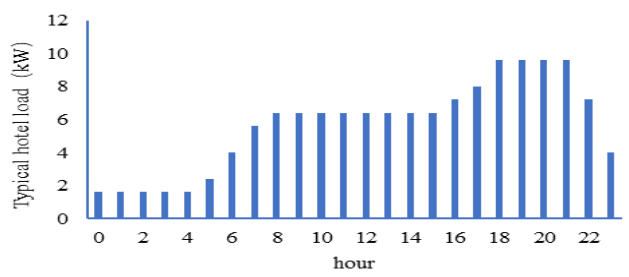

Fig. 5. Typical hotel daily load.

According to the relevant planning of the island, it can be predicted that the maximum residential load of the island is $180 \mathrm{~kW}$ in 2025 , the hotel load is up to $2100 \mathrm{~kW}$, and the total maximum load is $2280 \mathrm{~kW}$. 


\subsection{Device data}

The island can consider the use of wind power, photovoltaic, diesel generators, and energy storage devices in microgrids. Considering the island area and natural environment distribution of the island load situation, when constructing the model, it is mainly considered to introduce high-power diesel generator, $1.5 \mathrm{MW}$ wind turbine, photovoltaic power generation device, energy storage device (lead acid battery and lithium). Battery), power storage equipment (flywheel energy storage), inverters, and other devices. The main cost and technical information about these devices are shown in Table 1 and Fig. 6.

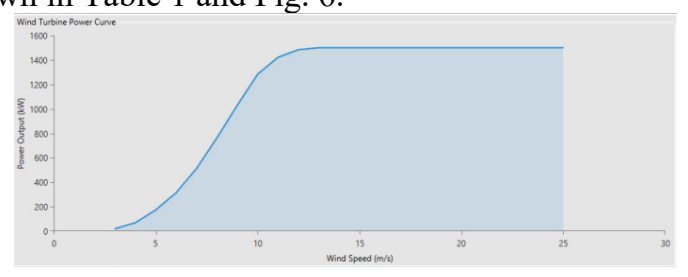

Fig. 6. Wind turbine output curve.

Table 1. Main data of Equipment

\begin{tabular}{|c|c|c|c|c|c|}
\hline $\begin{array}{l}\text { Compone } \\
\text { nt types }\end{array}$ & Model & $\begin{array}{c}\text { Cost of } \\
\text { purchase }\end{array}$ & $\begin{array}{c}\text { Replac } \\
\text { ement } \\
\text { costs }\end{array}$ & $\begin{array}{c}\text { Mainten } \\
\text { ance } \\
\text { costs }\end{array}$ & $\begin{array}{c}\text { Opera } \\
\text { ting } \\
\text { life }\end{array}$ \\
\hline $\begin{array}{c}\text { Diesel } \\
\text { generators }\end{array}$ & $\begin{array}{l}\text { Generic } \\
1 \mathrm{MW}\end{array}$ & $\$ 220 / \mathrm{kW}$ & $\begin{array}{c}\$ 220 / \mathrm{k} \\
\mathrm{W}\end{array}$ & $\begin{array}{l}\$ 5 / \text { Run } \\
\text { hour }\end{array}$ & $\begin{array}{c}25 \\
\text { years }\end{array}$ \\
\hline Fans & LTW86 & $\$ 600 / \mathrm{kW}$ & $\begin{array}{c}\$ 600 / \mathrm{k} \\
\mathrm{W}\end{array}$ & $\begin{array}{c}\$ 1500 / \text { ye } \\
\text { ar }\end{array}$ & $\begin{array}{c}25 \\
\text { years }\end{array}$ \\
\hline \multirow[b]{2}{*}{$\begin{array}{l}\text { Energy } \\
\text { battery }\end{array}$} & HIM & $\$ 209 / \mathrm{kWh}$ & $\begin{array}{c}\$ 100 / \mathrm{k} \\
\text { Wh }\end{array}$ & $\begin{array}{c}\$ 1 / \\
(\mathrm{kWh} \cdot \mathrm{y} \\
\text { ear) }\end{array}$ & $\begin{array}{c}15 \\
\text { years }\end{array}$ \\
\hline & $\begin{array}{c}\text { H2500( } \\
\text { Lead- } \\
\text { acid } \\
\text { battery) }\end{array}$ & $\$ 150 / \mathrm{kWh}$ & $\begin{array}{c}\$ 100 / \mathrm{k} \\
\text { Wh }\end{array}$ & $\begin{array}{c}\$ 1 / \\
(\mathrm{kWh} \cdot \mathrm{y} \\
\text { ear })\end{array}$ & $\begin{array}{c}15 \\
\text { years }\end{array}$ \\
\hline $\begin{array}{l}\text { Power } \\
\text { battery }\end{array}$ & Fly 100 & $\$ 3000 / \mathrm{kW}$ & $\begin{array}{l}\$ 2000 / \\
\mathrm{kW}\end{array}$ & $\begin{array}{c}\$ 10 / \\
(\mathrm{kW} \cdot \mathrm{ye} \\
\text { ar })\end{array}$ & $\begin{array}{c}15 \\
\text { years }\end{array}$ \\
\hline $\begin{array}{l}\text { Photovolt } \\
\text { aic }\end{array}$ & PV & $\$ 130 / \mathrm{kW}$ & $\begin{array}{c}\$ 130 / \mathrm{k} \\
\mathrm{W}\end{array}$ & $\begin{array}{c}\$ / 2.6 \\
(\mathrm{~kW} \cdot \mathrm{ye} \\
\text { ar })\end{array}$ & $\begin{array}{c}25 \\
\text { years }\end{array}$ \\
\hline Converter & $\begin{array}{l}\text { Convert } \\
\text { er }\end{array}$ & $\$ 200 / \mathrm{kW}$ & $\begin{array}{c}\$ 200 / \mathrm{k} \\
\mathrm{W}\end{array}$ & 0 & $\begin{array}{c}15 \\
\text { years }\end{array}$ \\
\hline
\end{tabular}

\section{Comparative Analysis of Microgrid Configuration}

Three microgrid configuration is proposed for the situation of the island: diesel generators only; renewable energy units only; hybrid networking.

\subsection{Diesel generator only}

According to the results of HOMER, in the diesel-only mode, the optimal system consists of two 1MW diesel generators and a $613 \mathrm{~kW}$ battery energy storage system. In this mode, the NPC is $\$ 24.42$ million, the average of the system. The cost of generating electricity (COE) is $\$ 0.315 / \mathrm{kWh}$, and the annual operating cost is $\$ 1.84$ million.

The system emissions are detailed in Table 2.
Table 2. Diesel-only networking information

\begin{tabular}{|c|c|}
\hline Name of emissions & Emissions \\
\hline Carbon dioxide & $4,193,188 \mathrm{~kg} /$ year \\
\hline Carbon monoxide & $21,693 \mathrm{~kg} /$ year \\
\hline Unburned hydrocarbons & $1,151 \mathrm{~kg} /$ year. \\
\hline Particulate matter & $185 \mathrm{~kg} / \mathrm{year}$. \\
\hline Sulfur dioxide & $10,250 \mathrm{~kg} /$ year \\
\hline Nitrogen oxides & $4,158 \mathrm{~kg} /$ year. \\
\hline
\end{tabular}

\subsection{Renewable energy only}

According to the results of HOMER, in the mode of operation of the fully renewable energy unit, the optimal results are as follows: the system has $2200 \mathrm{kWp}$ photovoltaic, $1.5 \mathrm{MW}$ wind power and $99553 \mathrm{kWh}$ leadacid battery. In this mode, the NPC is 69.3 million. Dollar. The system's average power generation cost is $\$ 0.895 / \mathrm{kWh}$, and the annual average operating cost is $\$ 1.18$ million.

The system is wholly networked by renewable energy systems without any emissions.

\subsection{Hybrid networking}

According to the calculation results of HOMER, in the mode of operation of all-renewable energy units, there are a variety of relatively close networking modes. Table 3 summarizes the above information.

Table 3. Hybrid networking information

\begin{tabular}{|c|c|c|c|}
\hline Components & Scenario I & Scenario II & Scenario III \\
\hline $\begin{array}{c}\text { Diesel } \\
\text { generators }\end{array}$ & $2000 \mathrm{~kW}$ & $2000 \mathrm{~kW}$ & $1000 \mathrm{~kW}$ \\
\hline Fans & $1,500 \mathrm{~kW}$ & $1,500 \mathrm{~kW}$ & $1,500 \mathrm{~kW}$ \\
\hline PV & $2166 \mathrm{kWp}$ & $2159 \mathrm{~kW}$ & $2123 \mathrm{~kW}$ \\
\hline $\begin{array}{c}\text { Energy } \\
\text { storage } \\
\text { batteries }\end{array}$ & $10830 \mathrm{kWh}$ & $\begin{array}{c}10755 \mathrm{kWh}+ \\
500 \mathrm{~kW}\end{array}$ & $10615 \mathrm{kWh}$ \\
\hline NPC & $\$ 8.77 \mathrm{million}$ & $\$ 93.3 \mathrm{million}$ & $\$ 10.1 \mathrm{million}$ \\
\hline COE & $\$ 0.013 / \mathrm{kWh}$ & $\$ 0.120 / \mathrm{kWh}$ & S0.130/kWh \\
\hline $\begin{array}{c}\text { Initial } \\
\text { investment }\end{array}$ & $\$ 56.3 \mathrm{million}$ & $\$ 61.2 \mathrm{million}$ & $\$ 68.7 \mathrm{million}$ \\
\hline $\begin{array}{c}\text { Percentage of } \\
\text { renewable } \\
\text { electricity }\end{array}$ & $89.6 \%$ & $89.0 \%$ & $90.0 \%$ \\
\hline
\end{tabular}

As can be seen from Table 3, the scenario I is the best solution, scheme, and the scheme 1 achieves a higher proportion of renewable energy power generation when the cost is lower than that of the scheme 2, although the proportion of renewable energy generation in the first scheme is slightly lower. However, its net present value cost is $15 \%$ lower than that of the third option, and the initial investment of the first option is $22 \%$ lower than the third option. Moreover, considering the extreme weather of the island, the dual fuel unit configuration in Option 1 can ensure that the island meets the full load of the island in extreme weather, and option one is selected as the optimal solution.

By summarizing the simulation results above, we can get the Table 4 and Table 5, 
Table 4. Summary of three types of configuration emission

\begin{tabular}{|c|c|c|c|}
\hline $\begin{array}{c}\text { Name of } \\
\text { emissions }\end{array}$ & Diesel-only & $\begin{array}{c}\text { Renewable- } \\
\text { only }\end{array}$ & $\begin{array}{c}\text { Hybrid } \\
\text { Network 1 }\end{array}$ \\
\hline Carbon dioxide & $\begin{array}{c}4,193,188 \mathrm{~kg} / \\
\text { year. }\end{array}$ & 0 & $\begin{array}{c}436,091 \mathrm{~kg} / \\
\text { year. }\end{array}$ \\
\hline $\begin{array}{c}\text { Carbon } \\
\text { monoxide }\end{array}$ & $\begin{array}{c}21,693 \mathrm{~kg} / \\
\text { year. }\end{array}$ & 0 & $\begin{array}{c}2256.072 \mathrm{~kg} / \\
\text { year. }\end{array}$ \\
\hline $\begin{array}{c}\text { Unburned } \\
\text { hydrocarbons }\end{array}$ & $1,151 \mathrm{~kg} /$ year. & 0 & $\begin{array}{c}119,704 \mathrm{~kg} / \\
\text { year. }\end{array}$ \\
\hline $\begin{array}{c}\text { Particulate } \\
\text { matter }\end{array}$ & $185 \mathrm{~kg} /$ year. & 0 & $\begin{array}{c}19.24 \mathrm{~kg} / \\
\text { year. }\end{array}$ \\
\hline Sulfur dioxide & $\begin{array}{c}10,250 \mathrm{~kg} / \\
\text { year. }\end{array}$ & 0 & $\begin{array}{c}1,066 \mathrm{~kg} / \\
\text { year. }\end{array}$ \\
\hline Nitrogen oxides & $4,158 \mathrm{~kg} /$ year. & 0 & $\begin{array}{c}432.43 \mathrm{~kg} / \\
\text { year. }\end{array}$ \\
\hline
\end{tabular}

Table 5. Summary of three types of configuration cost

\begin{tabular}{|c|c|c|c|}
\hline Cost type & Diesel-only & $\begin{array}{c}\text { Renewable } \\
\text { energy } \\
\text { generation } \\
\text { only }\end{array}$ & $\begin{array}{c}\text { Hybrid } \\
\text { networking }\end{array}$ \\
\hline NPC & $\$ 24.42$ million & $\$ 69.3$ million & $\$ 8.77$ million \\
\hline COE & $\$ 0.315 / \mathrm{kWh}$ & $\$ 0.895 / \mathrm{kWh}$ & $\$ 0.130 / \mathrm{kWh}$ \\
\hline $\begin{array}{c}\text { Operating } \\
\text { Cost( OC) }\end{array}$ & $\$ 18.4$ million & $\$ 11.8$ million & $\$ 26.3$ million \\
\hline
\end{tabular}

Comparing the Table 4 and the Table 5, under the premise of considering environmental friendliness, the scheme of power supply for all diesel generators should be excluded first. In this scheme, the pollutant emissions are significant. Secondly, considering the economic problem, it is known from Table 5 that in the case of considering the economy, the hybrid network model has an advantage, and it is subject to natural resources. When adopting only renewable generator sets for networking, a large amount of storage batteries need to be equipped. The ability to the battery, or to install a more substantial capacity of the generator set, resulting in a significant increase in operating costs and the initial cost of the system economic deterioration. From the perspective of system backup, the coal-fired generator set with hybrid networking can meet the demand for electricity when the system loses all renewable power and meets the tourism planning of the island.

\section{Concluding Remarks}

In this paper, the HOMOER model is used to simulate and optimize the microgrid network optimization of the sightseeing island, and it is concluded that for the island, the system adopting the scenery and storage system is more desirable than the pure diesel storage system and the wind storage system. Compared with the wind and light storage system, the wind and light wood storage system is more economical, and can obtain a higher standby rate at a lower cost, and meets the demand for stable power supply for the sightseeing offshore island in extreme weather. Moreover, it can be more flexible to deal with the load demand during the peak travel season.

Based on the comparison process, this paper proposes the optimization process of the sightseeing offshore microgrid. Compared with the general offshore island microgrid planning, the tourism-type island planning needs to strengthen the restrictions on pollutant emissions, and as a primary consideration, and secondly, the system's standby rate needs to be considered in the planning. This is also the HOMER software. The shortcomings of the simulation, in the end, for the sightseeing islands, the economic problems can be relaxed.

\section{Acknowledgment}

This work is funded by the State Grid Science and Technology Project of China (Research on Design and Pricing Technology of Power Finance Products).

\section{References}

1. C. Xue, "Island Wind Power serves the National Ocean Strategy", Wind Energy, vol. 7, pp. 26-28, July 2011.

2. P. Q. Zhou, J. R. Mao, H. W. Ma, M. P. Fu, "Investigation for steady control of independent island electrical power supply system including high penetration distributed power supply", Power System Protection and Control, Vol. 41, pp. 84-90, Jan. 2011.

3. M. X. Liu, L. Guo, B. Zhao, X. S. Zhang, Y. Liu, “A Coordinated Operating Control Strategy for Hybrid Isolated Microgrid Including Wind Power", Photovoltaic System, Diesel Generator, and Battery Storage", Automation of Electric Power Systems, Vol. 36, pp. 19-24, Cot. 2012.

4. K. Wang, W. Y. Li, X. F. Zhang, X. L. Bai, "Impact of Photovoltaic Generation on Reliability of Small Isolated PV-Wind-Diesel-Battery Power Generation System", Power System Technology, Vol. 37, pp. 3096-3100, Nov. 2013.

5. N. Wang, "The operation strategy and optimal planning method of the stand-alone microgrid including wind turbine, photovoltaic, hydro turbine, diesel generator and energy storage system", Tian Jin University, 2017.

6. M. X. Liu, C. S. Wang, L. Guo, B. Zhao, X. S. Zhang, Y. Liu, "An Optimal Design Method of Multi-objective Based Island Microgrid", Automation of Electric Power Systems, Vol. 36, pp. 34-39, Oct. 2012.

7. Z. Y. Yang, H. W. Ma, J. R. Mao, "Optimal Combination Technology of Island Microgrid", Electric Power Construction, Vol. 35, pp. 63-68, July. 2014.

8. K. L. Wang, Y. G. You, Y. Q. Zhang, "Energy Management System of Renewable Stand-alone Energy Power Generation System in an Island", Automation of Electric Power Systems, Vol. 34, pp. 13-17, Nov. 2010.

9. Z. X. Lu, et. al, "Overview on Microgrid Research", Automation of Electric Power Systems, Vol. 31, pp. 100-107, Nov. 2007. 